\title{
MOTIVASI KERJA MENINGKATKAN MANAJEMEN WAKTU PERAWAT
}

\author{
Iin Inayah ${ }^{1,2^{*}}$, Budi Anna Keliat ${ }^{3}$, Dewi Gayatri ${ }^{3}$ \\ 1. STIKES Jenderal Achmad Yani Cimahi, Jawa Barat 40633, Indonesia \\ 2. Program Studi Magister Fakultas Ilmu Keperawatan Universitas Indonesia, Depok 16424, Indonesia \\ 3. Fakultas Ilmu Keperawatan Universitas Indonesia, Depok 16424, Indonesia \\ *Email:inayah_2006@yahoo.co.id
}

\begin{abstract}
Abstrak
Data survey menyatakan belum optimalnya manajemen waktu dan motivasi kerja perawat. Tujuan penelitian untuk mendapatkan gambaran dan hubungan yang paling signifikan antara aspek motivasi kerja dengan manajemen waktu, dikontrol oleh karakteristik perawat. Analisis data dengan menggunakan Chi-square dan regresi logistik ganda. Penelitian di instalasi rawat inap RS di Bogor menggunakan sampel 138 perawat pelaksana. Hasil penelitian menunjukkan bahwa perawat pelaksana dengan "kebutuhan mempengaruhi" yang tinggi mempunyai peluang 5,7 kali melakukan manajemen waktu yang lebih baik. Perawat pelaksana dengan "kebutuhan berprestasi" yang tinggi mempunyai peluang 2,7 kali melakukan manajemen waktu yang baik. Saran penelitian ini yaitu perlunya stimulus dalam meningkatkan motivasi kerja, penempatan dan audit dalam pelaksanaan manajemen waktu perawat.
\end{abstract}

Kata Kunci: kebutuhan afiliasi, kebutuhan berprestasi, kebutuhan mempengaruhi, manajemen waktu, motivasi kerja

\begin{abstract}
Data survey said not optimally time management and work motivation in Bogor Hospital. This study is description and to see what has most significant relationship between work motivation and time management was controlled with nurse characteristics. Data analysis using Chi-square and multiple logistic regression. Place research is in hospitalized patient at Bogor Hospital with 138 nurse as sample. The result was indicated that a nurse who have motivation "need of power" had 5.6 better in time management, and for a nurse who have work motivation "need of achievement" had 2.7 better time management. The recommendation is need for give stimulus work motivation, replacement and than audit for time management of nurse.
\end{abstract}

Keywords: need of affiliation, need of achievement, need of power, time management, work of motivation

\section{Pendahuluan}

Peningkatan kualitas dari pelayanan keperawatan diupayakan dengan melalui pemberdayaan tenaga keperawatan. Tenaga perawat pelaksana itu sendiri merupakan tenaga kerja yang berinteraksi 24 jam dengan klien. Dalam pelayanannya, diperlukan manajemen waktu yang berasal dari motivasi kerja seorang perawat pelaksana.

Motivasi kerja dan manajemen waktu perawat terlihat melalui hasil observasi dan wawancara perawat. Hasil studi pendahuluan yang penulis peroleh di sebuah RS di daerah Bogor ditemukan data belum optimal tujuan pelayanan keperawatan dan belum sesuai dengan visi misi keperawatan. Data lain yang diperoleh yaitu belum optimalnya pembuatan rencana harian perawat dan belum optimalnya pengorganisasian waktu pembuatan dokumentasi asuhan keperawatan. Jenjang karir perawat yang belum jelas, belum adanya program penghargaan perawat berdasarkan kompetensi perawat, dan belum optimal audit keperawatan.

Hasil wawancara perawat pelaksana rawat inap di sebuah RS daerah Bogor diperoleh data yaitu belum jelasnya karir perawat, belum optimalnya penghargaan terhadap kompetensi perawat dan belum optimal audit keperawatan menyebabkan motivasi kerja perawat menurun. Pendapat Lakein (1984) dan Stewart (1993) yang menyatakan bahwa motivasi kerja merupakan salah satu faktor yang mempengaruhi manajemen waktu kerja. Berdasarkan studi pendahuluan dan konsep tersebut penulis tertarik melakukan penelitian hubungan antara motivasi kerja dengan manajemen waktu perawat pelaksana instalasi rawat inap sebuah RS di daerah Bogor. 
Ketertarikan penulis dalam penelitian bertujuan mendapatkan gambaran aspek motivasi kerja kebutuhan berprestasi, kebutuhan mempengaruhi, kebutuhan afiliasi, dan manajemen waktu. Tujuan lainnya yaitu melihat hubungan antara aspek motivasi kerja kebutuhan berprestasi, kebutuhan mempengaruhi, dan kebutuhan afiliasi dengan manajemen waktu. Tujuan akhirnya adalah melihat hubungan yang paling bermakna antara aspek motivasi kerja tersebut dengan manajemen waktu yang dapat dikontrol oleh karakteristik perawat.

\section{Metode}

Penelitian ini menggunakan metode penelitian deskripsi korelasi, dengan cara pengumpulan data cross sectional. Analisis univariat penelitian ini menggunakan uji deskriptif, bivariat dengan $\mathrm{Chi}$ square, dan multivariat dengan regresi logistik ganda. Penelitian dilakukan di instalasi rawat inap sebuah rumah sakit daerah Bogor dengan sampel 138 perawat pelaksana. Hasil metode kuantitatif yang terlihat berupa angka, yang diuraikan dalam hasil penelitian.

\section{Hasil}

Hasil penelitian ini merupakan hasil dari instrumen penelitian. Data karakteristik perawat rawat inap sebuah rumah sakit daerah Bogor sebagian besar dalam masa produktif. Umur perawat rerata 31 tahun. Lama masa kerja perawat memiliki rerata 5 tahun. Sebagian besar responden wanita $(80,4 \%)$, dengan status kepegawaian swasta $(89,9 \%)$, sudah menikah (71\%), dan berpendidikan tinggi $(53,6 \%)$. Data karakteristik perawat yang produktif tersebut menunjang hasil univariat penelitian.

Hasil penelitian univariat menunjukkan sebagian besar faktor motivasi dan kinerja manajemen waktu perawat rawat inap RS daerah Bogor menunjukkan hasil yang baik. Sebagian besar motivasi kerja perawat tinggi $(55,1 \%)$, kebutuhan berprestasi tinggi $51,4 \%$, kebutuhan mempengaruhi tinggi $69,6 \%$, dan kebutuhan afiliasi tinggi $67,4 \%$. Sebagian perawat memiliki manajemen waktu baik $(55,8 \%)$, dengan perencanaan yang baik $(53,6 \%)$, pengorganisasian baik $(51,8 \%)$, pelaksanaan baik (50\%), dan evaluasi baik $(56,5 \%)$. Hasil penelitian univariat independen dan dependen yang baik mendukung hasil bivariat penelitian.

Tabel 1 menunjukkan bahwa ada hubungan yang bermakna antara motivasi kerja dengan manajemen waktu ( $p=0,000 ; \alpha=0,05)$. Hasil bivariat yang berhubungan dalam penelitian ini adalah kebutuhan berprestasi dan kebutuhan mempengaruhi $(\mathrm{p}=$ $0,002 ; p=0,000 ; \alpha=0,05)$. Sementara kebutuhan afiliasi tidak berhubungan dengan manajemen waktu perawat pelaksana ( $\mathrm{p}=0,340 ; \alpha=0,05)$.

Tabel 2 menunjukkan bahwa hubungan yang paling bermakna, yaitu aspek motivasi kerja kebutuhan mempengaruhi ( $\mathrm{p}=0,000 ; \alpha=0,05)$. Selanjutnya, aspek motivasi kerja kebutuhan berprestasi dengan manajemen waktu tanpa dikontrol karakteristik perawat $(p=0,016 ; \alpha=0,05)$. Hasil penelitian ini sesuai dengan teori Christian (2004); Gymnastiar (2001); Timpe (2000); Treacy (2003), yang mengungkapkan aspek motivasi kerja kebutuhan afiliasi dengan manajemen waktu menunjukkan tidak ada hubungan yang bermakna. Kebutuhan mempengaruhi yang tinggi pada perawat pelaksana sebuah rumah sakit di Bogor dapat meningkatkan 5,837 kali manajemen waktu perawat pelaksana. Sementara kebutuhan berprestasi yang tinggi pada perawat pelaksana sebuah rumah sakit di Bogor dapat meningkatkan 2,557 kali manajemen waktu perawat pelaksana.

Peluang manajemen waktu baik dari perawat pelaksana dengan kebutuhan mempengaruhi dan kebutuhan berprestasi tinggi adalah:

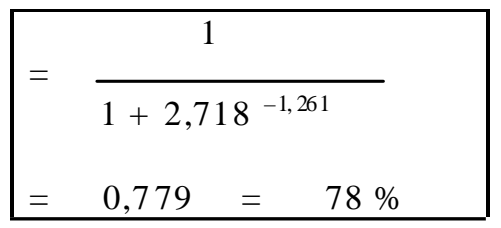

Perawat pelaksana sebuah rumah sakit daerah Bogor dengan kebutuhan mempengaruhi tinggi dan dikontrol dengan kebutuhan berprestasi tinggi memiliki peluang melakukan manajemen waktu yang baik $78 \%$. 
Tabel 1. Hubungan Motivasi Kerja, Kebutuhan Berprestasi, Kebutuhan Mempengaruhi, dan Kebutuhan Afiliasi dengan Manajemen Waktu Perawat Pelaksana Rawat Inap

\begin{tabular}{|c|c|c|c|c|c|c|c|c|}
\hline \multirow{3}{*}{ Aspek Motivasi } & \multicolumn{4}{|c|}{ Manajemen Waktu } & \multirow{2}{*}{\multicolumn{2}{|c|}{ Total }} & \multirow{3}{*}{ OR $95 \%$ CI } & \multirow{3}{*}{$\mathbf{p}$} \\
\hline & \multicolumn{2}{|c|}{ Buruk } & \multicolumn{2}{|c|}{ Baik } & & & & \\
\hline & $\mathbf{n}$ & $\%$ & $\mathbf{N}$ & $\%$ & $\mathbf{n}$ & $\%$ & & \\
\hline Motivasi Kerja & & & & & & & & \\
\hline a. Rendah & 39 & 62,9 & 23 & 37,1 & 62 & 100,0 & 4,162 & 0,000 \\
\hline b. Tinggi & 22 & 28,9 & 54 & 71,1 & 76 & 100,0 & $(2,036-8,508)$ & \\
\hline Kebutuhan Berprestasi & & & & & & & & \\
\hline a. Rendah & 39 & 58,2 & 28 & 41,8 & 67 & 100,0 & 3,102 & 0,002 \\
\hline b. Tinggi & 22 & 31,0 & 49 & 69,0 & 71 & 100,0 & $(1,542-6,241)$ & \\
\hline Kebutuhan Mempengar & & & & & & & & \\
\hline a. Rendah & 31 & 73,8 & 11 & 26,2 & 42 & 100,0 & 6,200 & 0,000 \\
\hline b. Tinggi & 30 & 31,3 & 66 & 68,8 & 96 & 100,0 & $(2,753-13,965)$ & \\
\hline Kebutuhan Afiliasi & & & & & & & & \\
\hline a. Rendah & 23 & 51,1 & 22 & 48,9 & 45 & 100,0 & 1,513 & 0,340 \\
\hline b. Tinggi & 38 & 40,9 & 55 & 59,1 & 93 & 100,0 & $(0,740-3,096)$ & \\
\hline
\end{tabular}

Besar peluang manajemen waktu yang baik pada perawat pelaksana sebuah rumah sakit daerah Bogor dengan kebutuhan mempengaruhi dan kebutuhan berprestasi rendah dengan nilai 0 , sebagaimana berikut:

$\begin{aligned} & \text { Peluang manajemen waktu } \\ & \text { baik perawat pelaksana }\end{aligned}$
$\begin{aligned} & \mathrm{Z} \quad=-1,472+1,732(0)+1,001(0) \\ & =-1,472\end{aligned}$

Peluang manajemen waktu baik dari perawat pelaksana dengan kebutuhan mempengaruhi dan kebutuhan berprestasi rendah adalah:

$$
\begin{aligned}
\mathrm{F}(\mathrm{x}) & =\frac{1}{1+2,718^{1,472}} \\
& =0,187 \\
& =19 \%
\end{aligned}
$$

Tabel 3 menunjukkan bahwa perawat pelaksana sebuah rumah sakit di daerah Bogor memiliki kebutuhan mempengaruhi rendah yang dikontrol kebutuhan berprestasi rendah mempunyai peluang untuk melakukan manajemen waktu yang baik 19\%. Kesesuaian dan kesenjangan dengan teori konsep penelitian ini, serta aplikasi penelitian ini terdapat dalam pembahasan.

\section{Pembahasan}

Perawat pelaksana rawat inap sebuah rumah sakit daerah Bogor lebih dari setengah $(51,4 \%)$ memiliki kebutuhan berprestasi, potensi tinggi untuk menjadi yang terbaik, mencapai keberhasilan sesuai standar, dan berjuang untuk kesuksesan. Perawat pelaksana berkebutuhan berprestasi lebih menyukai adanya tantangan dalam pekerjaan dan menerima tanggung jawab pribadi atas kesuksesan atau kegagalannya.

Perawat pelaksana dengan kebutuhan perprestasi tinggi tidak suka membiarkan masalah selesai dengan secara kebetulan atau diselesaikan oleh orang lain. Perawat pelaksana dengan kebutuhan berprestasi juga tidak menyukai pekerjaan dengan derajat kesukaran yang rendah karena tidak ada tantangan. Perawat tersebut lebih berorientasi pada suksesnya penyelesaian tugas dalam perhitungan yang cermat dan menyukai umpan balik dari pekerjaannya (Agarwal, 1986; Adikoesoemo, 1997; Muchlas, 1999). Bidang keperawatan dan kepala ruangan $\mathrm{RS}$ dapat meningkatkan motivasi kerja perawat pelaksana dengan memberikan beberapa tantangan untuk kemajuan perawat pelaksana dalam pekerjaan. Upaya tersebut dilakukan dengan memberi kesempatan optimal terhadap perawat mengalami perasaan keberhasilan dan kepuasan dari usaha mereka dalam program jenjang karir perawat (Muchlas, 1999). 
Stimulus motivasi tersebut akan membuat perawat mempunyai keinginan dan kebutuhan dalam pengembangan kompetensinya. Perawat pelaksana tersebut akan melakukan pekerjaan berdasarkan perhitungan yang cermat, dengan menggunakan resiko moderat yang mendekati area klien. Perawat pelaksana menjadi dapat melakukan pelayanannya secara integral, tegas, berdasar ilmu dan kenyataan yang akan dirasakan oleh kepuasan kerja perawat dan kepuasan klien (Danim, 2004).

Sebagian besar $(69,6 \%)$ perawat pelaksana RS di Bogor memiliki kebutuhan mempengaruhi tinggi untuk membuat orang lain berperilaku dengan caracara yang perawat tersebut kehendaki. Perawat pelaksana yang memiliki kebutuhan mempengaruhi lebih menyukai ditempatkan pada posisi dengan wewenang/job description jelas, berkompetisi, dan berorientasi terhadap prestise sesuai dengan kompetensi dalam pengembangan pengetahuan dan keterampilan melalui peningkatan pendidikan formal (Agarwal, 1986; Adikoesoemo, 1997; Muchlas, 1999). Perawat pelaksana berkebutuhan mempengaruhi tinggi akan selalu menikmati tugastugas perjuangan untuk mempengaruhi orang lain dalam pelayanan tugas (Muchlas, 1999). Perawat pelaksana RS Bogor memiliki kebutuhan afiliasi tinggi $(67,4 \%)$. Dalam penelitian ini, perawat dengan kebutuhan afiliasi tinggi akan lebih lambat dalam manajemen waktu. Hal ini disebabkan oleh afiliasi butuh waktu lebih dalam berinteraksi pada interpersonal. Suasana kekeluargaan yang kondusif bagi perawat maupun pelayanan dapat diupayakan untuk meningkatkan peningkatan kebutuhan motivasi kerja afiliasi.

Perawat dengan kebutuhan afiliasi tinggi memiliki keinginan memiliki hubungan persahabatan atau hubungan antara manusia secara dekat. Perawat pelaksana berkebutuhan afiliasi tinggi berkeinginan untuk disukai dan diterima orang lain, berjuang untuk persahabatan sehingga lebih menyukai situasi kooperatif. Perawat pelaksana berkebutuhan afiliasi tinggi berkeinginan memiliki hubungan penuh pengertian dan saling menguntungkan (Adikoesoemo, 1997; Agarwal, 1986; Muchlas, 1999). Keberhasilan perawat pelaksana dengan kebutuhan afiliasi tinggi ditetapkan apabila dapat menjalin hubungan dengan rekan kerja dan klien. Bidang keperawatan dapat meningkatkan motivasi kerja perawat berkebutuhan afiliasi tinggi dengan menempatkan area kerja perawat tersebut dalam sosialisasi, hubungan antar rekan kerja, klien, dan masyarakat (Danim, 2004; Winardi, 2004).

Manajemen waktu perawat RS di Bogor dalam penelitian ini paling baik dilakukan adalah dalam perencanaan, sesuai dengan program RS yang sudah melaksanakan program penulisan rencana harian. Pengorganisasian perawat dilakukan pada pelaksanaan dan pengendaliannya belum sebaik pada tahap perencanaan dalam pelaksanaannya. Efektifitas kinerja perawat menunjukkan hasil yang berbeda, dimana dalam memberikan pelayanan keperawatan perlu dilatih atau dibudayakan dengan konsisten. Peningkatan yang masih diperlukan yaitu melakukan pengorganisasian, pelaksanaan dan pengendalian. Audit dalam manajemen waktu secara intensif sampai menjadi pembiasaan akan menjadi suatu karakter perawat tanpa disadari atau sudah terbiasa dan membudaya (Christian, 2004; Gymnastiar, 2001; Timpe 2000; Treacy, 2003).

Setengah dari perawat pelaksana RS menunjukkan manajemen waktu yang baik. Hal ini menunjukkan bahwa sebuah proses manajemen keperawatan yang baik berasal dari aspek motivasi kerja baik.

Tabel 2. Aspek Motivasi Kerja, Kebutuhan Berprestasi, Kebutuhan Mempengaruhi, dan Kebutuhan Afiliasi dengan Manajemen Waktu Perawat Pelaksana Rawat Inap

\begin{tabular}{lcccc}
\hline \multicolumn{1}{c}{ Variabel } & B & P Wald & OR & 95 \% CI \\
\hline Kebutuhan Prestasi & 0,939 & 0,016 & 2,557 & $1,191-5,488$ \\
Kebutuhan Mempengaruhi & 1,764 & 0,000 & 5,837 & $2,519-13,524$ \\
Kebutuhan Afiliasi & 0,359 & 0,386 & 1,432 & $0,636-3,223$ \\
\hline
\end{tabular}

- Log Likelihood= 159,824; G= 29,625; p= 0,000 
Budaya kerja tersebut perlu dipertahankan dan ditingkatkan, karena fokus pada input dan proses. Aspek motivasi kerja dan manajemen waktu adalah input dan proses yang akan menghasilkan output baik yaitu kinerja, kepuasan perawat pelaksana dan kepuasan klien (Azwar, 1996). Fenomena ini sering terbalik, yaitu fokus pada kualitas kinerja tanpa perhatikan motivasi kerja dan manajemen waktu. Peningkatan manajemen waktu berfokus pada input, dalam hal ini adalah motivasi kerja, dalam memperoleh suatu manajemen waktu yang baik dari motivasi kerja yang baik. Upaya ini adalah dengan meningkatkan motivasi kerja perawat yang memberikan suatu kemandirian/tidak bergantung diberikan motivasi, tetapi suatu motivasi dalam diri perawat (Azwar, 1996; Covey dalam Agustian, 2005). Hal ini adalah tantangan yang sebaiknya dilakukan bidang keperawatan, kepala instalasi rawat inap dan jajaran $\mathrm{RS}$.

Penunjang peningkatan manajemen waktu yaitu dengan cara peningkatan pendidikan formal dan informal. Pelatihan manajemen waktu yang dapat digunakan untuk peningkatan manajemen waktu, yaitu dengan menggunakan tahap perencanaan, pengorganisasian, pelaksanaan dan pengendalian (Timpe, 2000; Gymnastiar, 2001; Treacy, 2003; Christian, 2004). Dalam kegiatannya, perawat harus mampu mengalokasikan waktu $35 \%$ untuk asuhan keperawatan klien langsung, 20\% untuk pendokumentasian, $15 \%$ proses transaksi, $6 \%$ transportasi, $7 \%$ administrasi, $12 \%$ pelayanan departemen lain, dan 5\% lain-lain (Gillies, 1994).

Peningkatan pengetahuan dan keterampilan melalui pendidikan formal dan informal, membuat perawat

Tabel 3. Peluang Manajemen Waktu bagi Perawat Pelaksana Rawat Inap

pelaksana memiliki kemampuan mempengaruhi peningkatan kesehatan klien melalui kemampuan, sehingga manajemen keperawatan lebih optimal. Peningkatan pengetahuan ini akan menunjang manajemen keperawatan RS Bogor yang belum optimal dalam pelaksanaan tujuan dan visi-misi keperawatan, serta belum jelasnya jenjang karir. Standar asuhan keperawatan, penghargaan, dan program jenjang karir dengan kompetensi yang jelas dapat meningkatkan motivasi kebutuhan berprestasi dan manajemen waktu bagi perawat. Fasilitas yang disediakan bidang keperawatan RS Bogor akan membuat target/sasaran kebutuhan motivasi kerja perawat terpenuhi, tidak terjadi kekecewaan dan frustasi/stres, dan meningkatkan manajemen waktu secara optimal (Mardiyatmo, 2005; Muchlas, 1999 Danim, 2004; Winardi, 2004).

Hubungan kebutuhan afiliasi berbanding terbalik dengan kebutuhan kekuasaan dan berprestasi. Perawat berkebutuhan afiliasi akan menghasilkan manajemen waktu yang kurang kuat dibandingkan perawat yang memiliki kebutuhan kekuasaan dan prestasi, karena membutuhkan waktu yang lebih dalam berinteraksi dengan klien, tetapi kekuatan networking akan semakin kuat (Muchlas, 1999). Atasan dapat meningkatkan kebutuhan afiliasi perawat dengan cara meningkatkan kekeluargaan, budaya saling menerima/ sense of belonging, saling menghormati/ sense of importance, optimisme akan maju (sense of achievement), dan saling membantu/ sense of participation (Riduwan, 2004).

Perawat dengan motivasi kebutuhan berprestasi tinggi, dalam penelitian ini akan meningkatkan peluang 3,102 kali manajemen waktu perawatnya. Perawat kebutuhan berprestasi akan meyakini $\mathrm{F}(\mathrm{x})=\frac{\mathrm{e}=2,718}{1+\mathrm{e}^{-\mathrm{z}}}$
$\mathrm{z}=-1,472+1,732$ (kebutuhan me mpen garuhi tinggi) $+1,001$ (kebutuhan berprestasi tinggi)

\begin{tabular}{l} 
Peluang manajemen waktu baik perawat pelaksana $=$ \\
$\begin{array}{l}\mathrm{Z} \quad=-1,472+1,732(1)+1,001(1) \\
\quad=1,261\end{array}$ \\
\hline
\end{tabular}


dengan berprestasi kebutuhan terpenuhi, percaya dirinya akan meningkat dan pendapatannya dapat meningkat. Atasan yang menginginkan perawat optimal manajemen waktu dapat mengupayakan memberikan kejelasan kompetensi, jenjang karir, ajang prestasi, serta pendidikan formal dan informal perawat (Muchlas, 1999 Winardi, 2004; Danim, 2004; Mardiyatmo, 2005). Manajemen waktu akan membuat pelayanan semakin efektif dan produktif. Motivasi kerja perawat kebutuhan mempengaruhi tinggi, dalam penelitian akan meningkatkan 6,200 kali manajemen waktu. Kebutuhan mempengaruhi adalah sebuah nilai peningkatan besar dan paling besar daripada kebutuhan motivasi kerja lainnya yang paling berpengaruh pada manajemen waktu. Sesuai pendapat Monica (1998), bahwa perawat berkebutuhan mempengaruhi/jiwa kepemimpinan akan mempunyai manajemen waktu sangat baik.

Peningkatkan pengetahuan dan keterampilan yang menunjang posisi sesuai perawat dan peningkatan pendidikan formal dan informal menunjang posisi dapat meningkatkan manajemen waktu 6,200 dari manajemen waktu perawat. Peningkatan motivasi mandiri dalam fasilitas target, program, dan prinsip kerja yang kuat dapat menimbulkan etos kerja tanpa batas, akan kembali menghasilkan kepuasan dan reward bagi perawat (Agustian, 2005). Kejelasan kompetensi dan jenjang karir semakin memperjelas arah visi misi dan motivasi kerja untuk peningkatan manajemen waktu perawat. Upaya yang sudah dilakukan atasan perawat akan berbanding lurus dengan perolehan hasil yang akan diperoleh atasan perawat tersebut dari etos kerja perawatnya.

\section{Kesimpulan}

Hasil penelitian yang telah dilakukan menunjukkan motivasi berprestasi perawat pelaksana dipengaruhi manajemen waktu perawat. Peningkatan motivasi perawat pelaksana dalam berprestasi paling besar dipengaruhi kebutuhan mempengaruhi. Hal ini merupakan faktor motivasi yang paling bermakna berhubungan dengan manajemen waktu pada perawat pelaksana $(\mathrm{p}=0,000 ; \alpha=0,05)$. Bidang keperawatan disarankan meningkatkan motivasi kerja perawat pelaksana berkebutuhan tersebut, dengan menempatkan perawat pada posisi kerja dengan job description jelas dan berorientasi pada prestise. Indikator dan item motivasi kebutuhan mempengaruhi dapat dijadikan materi tes seleksi rekruitmen atasan perawat dalam penempatan struktural perawat (MS, JS, TN).

\section{Referensi}

Adikoesoemo, S. (1997). Manajemen rumah sakit (Edisi ketiga). Jakarta: Pustaka Sinar Harapan.

Agarwal, R.D. (1986). Organization and management. New Delhi: Tata Mc Graw-Hill.

Agustian, A.G. (2005). Rahasia sukses membangun kecerdasan emosi \& spiritual berdasarkan 6 rukun iman dan 5 rukun islam. Jakarta: Penerbit Arga.

Azwar, A. (1996). Pengantar administrasi kesehatan (Edisi ketiga). Jakarta: Binarupa Aksara.

Christian, M. (2004). Time management. Jakarta: Next Media.

Danim, S. (2004). Motivasi kepemimpinan \& efektifitas kelompok. Jakarta : Penerbit Rineka Cipta.

Gillies, D.A. (1994). Nursing management a system approach (3rd Ed.). Philadelphia: WB Saunders.

Gymnastiar, A. (2001). Kiat praktis manajemen waktu. Jakarta: Mutiara Qolbun Salim.

Lakein, A. (1984). How to get control of your time and your life. Gower: Reprint Publisher.

Mardiyatmo, E.U. (2005). Anekdot manajemen - kiatkiat meningkatkan motivasi dan profesionalisme kerja. Jakarta: Grasindo.

Monica. (1998). Kepemimpinan dan manajemen keperawatan. Jakarta: Penerbit buku kedokteran.

Muchlas, M. (1999). Perilaku organisasi. Yogyakarta: Penerbit Program Pasca Sarjana MARS UGM.

Riduwan. (2004). Metode dan teknik menyusun tesis. Alfabeta: Bandung.

Stewart. (1989). Keterampilan manajer. Jakarta: Gramedia.

Timpe, A.D. (2000). Seri manajemen sumber daya alam manusia: Manajemen Waktu (Edisi kelima). Jakarta: PT Gramedia.

Treacy, D. (2003). Successful time management in a week (Terj. Abdullah, H.M.A). Inggris: Hodder \& Stougton.

Winardi, J. (2004). Motivasi dan pemotivasian dalam manajemen. Jakarta : PT. Raja Grafindo Persada. 